\title{
SPEECH ACTS OF THE BRONTE SISTERS' CHARACTERS
}

\author{
Citra Suryanovika ${ }^{1}$, Irma Manda Negara ${ }^{2}$ \\ Sekolah Tinggi Bahasa Asing Pontianak, Pontianak, Indonesia ${ }^{1,2}$ \\ I'csuryanovika@yahoo.com; ${ }^{2}$ irmamanda87@hotmail.com
}

\begin{abstract}
The study was under descriptive qualitative research to identify the most dominant speech act of the Bronte Sisters' characters. The researchers collected 3,322 utterances from six characters of Charlotte Bronte's Jane Eyre (Jane Eyre and Edward Rochester), Emily Bronte's Wuthering Heights (Heathcliff and Catherine Earnshaw), and Anne Bronte's The Tenant of Wildfell Hall (Gilbert Markham and Helen Graham). MAXQDA 2018.1 supported the data analysis procedure; thus, coding was used in identifying speech acts. After coding implemented, the researchers analyzed the coding by using qualitative and quantitative compare groups, as well as document comparison chart in MAXQDA 2018.1 to check the most dominant use of speech acts in all characters. The study found that directive speech act is the most dominant speech act found in the Bronte sisters' characters, while the declarative speech act is the least speech act. Speech acts of the Bronte sisters' characters was expressed in declarative, interrogative and imperative forms. Besides, speech acts in these novels highlight the use of address term, epithet, expression (verb, adjective, modal verbs), exclamation, conditional clauses, hedges and affirmative answer.
\end{abstract}

Keywords: Speech Acts; Bronte sisters' novels; Wuthering Heights; Jane Eyre; The Tenant of Wildfell Hall

\section{Introduction}

Jane Eyre depicted as a brave, educated young woman in Charlotte Bronte's novel. The utterances of Jane Eyre show her courage and sincerity, Charlotte Bronte, the author of Jane Eyre, strengthened the character through her utterances, as seen in Jane Eyre's frank response to $\mathrm{Mr}$. Rochesters 'I am no bird; and no net ensnares me; I am a free human being with an independent will, which I now exert to leave you.' (Ch. 23, p. 293) after he compared her to a frantic bird. Although she was set to live in an orthodox boarding school which trained girls to be submissive women, she turns to be a woman who can independently make decision for herself.
Wang (2011:6) explained Jane Eyre's intellectuality seen from the use of language for self-reflection, which is then used to express her passions and feelings. Wang (2011) sees Jane Eyre's characters against the ordinary women's role in the social structure as the plot described marriage happened not because of mutual affection, but wealth and social status. Wang also explained that Charlotte Bronte condemned the marriage of convenience.

Meanwhile, Wuthering Heights is the first and only novel about love and vengeance written by Emily Bronte portraying Heathcliff as the central character whose full of hatred. Yang (2012) explained that the study of novel Wuthering Heights has been conducted 
under intrinsic or extrinsic approaches of literary criticism. Differently, The Tenant of Wildfell Hall is the second novel written by Anne Bronte that becomes the first modern feminist novel, "a critique to marriage and marital violence in the late 1840s" (Doub, 2015). The presentation of fictional or non-fictional literature actually can be analysed through the use of linguistic and non-linguistic contexts.

However, only some scholars use linguistic approaches to conduct depth analysis of fictional literature since they tend to place psychological or social approaches as a tool to analyse literature, novel in particular. Leech and Mick (2007:9) said that the use of language in a given context determines style; thus, there are linguistic habits of acknowledged authors such as Dickens, Proust, or Shakespeare, etc. Leech and Mick clearly argued that the study of texts through linguistic evidence provides a better understanding on how a language serves a remarkably artistic function.

In the study of pragmatics, someone commits to make locutionary acts, perlocutionary acts, and illocutionary acts when he/she produces an utterance. Saddock (2006: 54-55) explained that those three acts are Austin's notion which initially influences the development of speech acts. To sum up, types of speech acts include in illocutionary act category.

The categories refer to Searle are Assertives, Directives, Commissives, Expressives, and Declaration (Taavitsainen and Jucker, 2008). A study of speech acts in novel is possible as Busse (2008: 119) stated that the use of speech acts is not only in spoken language, but also written language.

Furthermore, these three novels of the Bronte Sisters so far described clearly under the intrinsic and extrinsic elements of literary criticism. The study using pragmatic tool on the Bronte Sisters was only conducted by Rohmah (2011) on Charlotte Bronte's Jane Eyre, and Ariyanti (2007) and Yiyin (2014) on Emily
Bronte's Wuthering Heights. After considering Leech and Mick (2007:9) and knowing the fact about the study of Bronte sisters' novels, the researchers aimed to study the style of Bronte sisters' characters particularly by identifying their speech acts. The researchers observed that the characters Edward Rochester, Jane Eyre, Heathcliff, Catherine Earnshaw, Helen Graham and Gilbert Markham may have Searle's speech act categories (representative, expressive, commissive, directive and declarative) which are used in accordance with the objectives. This article, on the other hand, was a result generated from the application of pragmatic coding through the qualitative analysis tool MAXQDA 2018. justifying the difference of this recent study from the former ones. The researchers believe that this research may induce academic and practical significance for academician, students or next researchers.

\section{Research Method}

The study is a qualitative research, as Kuckartz (2013, p.2) stated that qualitative data includes texts. In this study, the researchers collected the utterances of female and male main characters in Charlotte Bronte's Jane Eyre (2006), Emily Bronte's Wuthering Heights (1995) and Anne Bronte's The Tenant of Wildfell Hall (1996), which include phrases, clauses and sentences (texts) of Jane Eyre, Edward Rochester, Heathcliff, Catherine Earnshaw, Helen Graham and Gilbert Markham. Six characters were included in the study on the basis of the role of characters in the story, gender, and its distinctive linguistic components in the utterances. The researchers only chose main male and female characters of Bronte sisters' novels. Jane Eyre and Edward Rochester were female and male main characters of Charlotte Bronte's Jane Eyre, while Heathcliff and Catherine Earnshaw were female and male main characters who also the centre of Emily Bronte's 
Wuthering Heights. Likewise, Helen Graham and Gilbert Markham were female and male characters who mainly discussed in Anne Bronte's The Tenant of Wildfell Hall. In addition, the researchers considered the style of Bronte sisters' in accentuating the distinctive features of their six fictional characters through utterances of the characters.

The researchers collected the raw data including utterances and context by sequentially writing the source (chapter of the novel and page) in square brackets.

The researchers employed MAXQDA 2018.1 which requires coding. Therefore, the researchers imported some files of six characters' utterances into document system, and inserted codes into code system. The codes were determined by referring to Hsieh and Shannon (2005:p.1286), they were defined before and during data analysis process, and the study used Searle's speech act categories pertaining to representative, commissive, expressive, directive, and declarative speech acts. In coding, the researchers considered the context of each utterance to make sure that the implied messages of each character are correctly checked. The data analysis was implemented after coding, the researchers chose qualitative and quantitative compare groups, as well as document comparison chart in MAXQDA 2018.1 to check the most dominant use of speech acts in all characters. The qualitative compare groups only used to present the characters' utterances which identified into types of speech acts, while the quantitative compare group displays the quantity of each speech act.

\section{Findings and Discussion.}

The researchers found 3,322 utterances made by Jane Eyre, Edward Rochester, Heathcliff, Catherine Earnshaw, Gilbert
Markham and Helen Graham addressing to all characters in the novels. The following chart (Chart 1) affirms that Charlotte Bronte's Jane Eyre has a great number of utterances of male and female main characters, while Emily Bronte's Wuthering Height which has Heathcliff and Catherine Earnshaw as the male and female main characters has the least number of utterances.

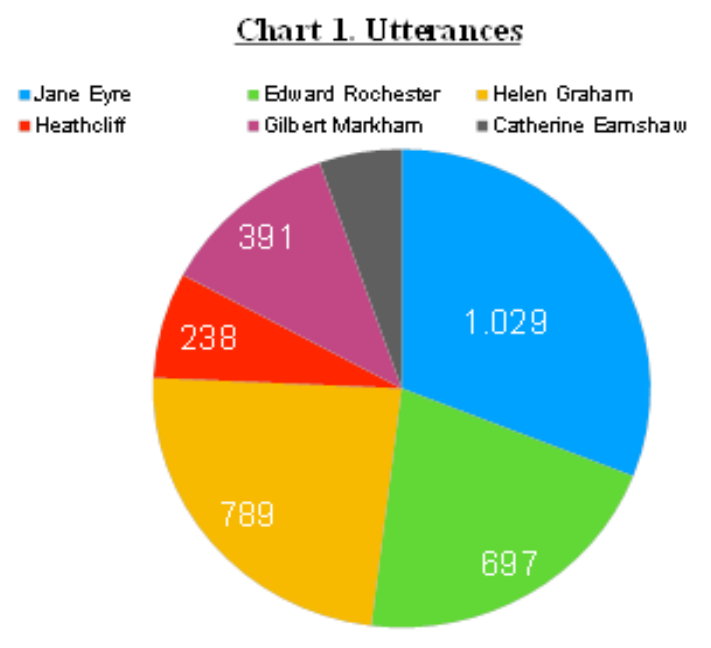

This is actually found because Catherine Earnshaw, the female character in Wuthering Heights, only has 178 utterances because this character only existed until the second chapter of volume two. In addition, only the story of Emily Bronte's Wuthering Heights that has a tragic ending since Heathcliff prioritized his revenge on the Earnshaw during his life; thus, his love life is not as happy as Edward Rochester-Jane Eyre and Gilbert Markham-Helen Graham.

Types of narration used by the author actually influence the result shown in preceding chart (Chart 1). It was proved that Charlotte Bronte's Jane Eyre employing first-person narrator (the female character, Jane Eyre), while Emily Bronte's Wuthering Heights puts third- 
person narrators to tell the story. In the meantime, the story of The Tenant of Wildfell Hall written by Anne Bronte was told through some letters of Gilbert

Markham to his friend, and the journal of Helen Graham.

After comparing the code frequencies in each document, it is found that directive speech act frequently found in all characters, as seen in the following Chart 2 about types of speech acts.

\section{Chart 2. Types of Speech}

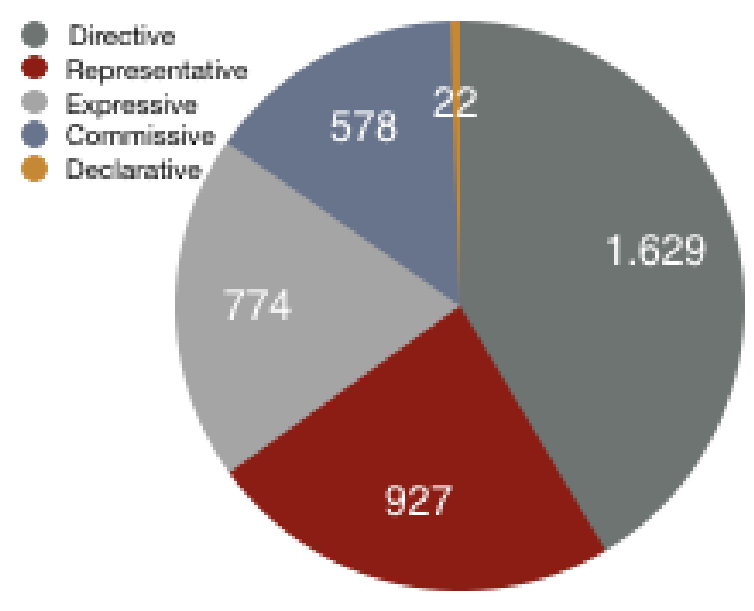

Subsequently, there are representative, expressive and commissive and declaration speech acts. The former five speech acts found in six characters, and the latter only found in five characters (except Gilbert Markham).

In directive speech acts, six characters asked, requested, suggested and ordered their addressees. The use WHquestion, modals, auxiliary verbs or question tags determine the form of questions. The questions using $\mathrm{WH}-$ question form or modals emphasise the interrogative form of the utterance.

(65) 'Who is to separate us, pray?

[Ch.9,p 82]

(201) 'Why did you not come to hear my explanation on the day I appointed to give it?' [Ch.15, p. 123]

(14) 'What is it that constitutes virtue, Mrs. Graham?’ [Ch.3, p. 31]
(10) 'Can you tell me where he is?' [Ch.12 p.134]

The utterances of Catherine Earnshaw (65). Helen Graham (201), Gilbert Markham (14), and Edward Rochester (10) exemplified the WHQuestion forms and modals in interrogative form. Besides, the use of modal verbs in (10) indicated that the question was indirect question.Differently, The questions in declarative form used question tag as found in Caherine Earnshaw's utterance (63) He has not, has he? [Ch.9,p 81], or used adverb then as seen in Helen Graham's utterance (340) 'Then you won't go to London, Arthur?' [Vol. II. Ch.24, p.215], or Edward Rochester who asked (9) 'He is not resident, then?' [Ch.12 p.134], as well as Jane Eyre's utterance in asking (175) "So I think: you have no ghost, then?' [Ch.11, P.125].

The statements functioned as questions also found in Gilbert Markham's, Jane Eyre's and Edward Rochester's utterances which have question marks. In (309) You will go to her, Lawrence?' [Vol. III. Ch.50, p.449], Gilbert Markham asked about Lawrence's plan who will meet his sister, Helen Graham. Meanwhile, Jane Eyre asked (921) 'You said he was alive?' [Ch. 36, p.494] to the coachman about the incident happened to Edward Rocherter in Thornfield Hall. Likewise, Edward Rochester in (65) 'And you felt selfsatisfied with the result of your ardent labours?' [Ch.13 p.148] also has question mark indicating a question addressed to Jane Eyre.

The study interestingly found that Heathcliff of Wuthering Heights employed special address terms in his questions to his addressees as seen in the following utterances:

(13) Where is she-my amiable lady?'

[Ch.2, p.14]

(238) 'Will you come, chuck? [Vol II, Ch.20 ,p. 334] 
(197) What's to do now, my lad? [Vol II, Ch.17,p. 303]

Heathcliff in (13) refers to Catherine Linton (his daughter in law) in mentioning my amiable lady. He actually repeated Lockwood's question about the lady who lives with Heathcliff. In the utterance (238), Heathcliff also addressed Catherine Linton by using the word chuck, which was a friendly address form, while he used my lad refering to Lockwood. Briefly, the uses of address terms used by Heathcliff actually show that he tended to address his addressees to to maintain informal discussion.

The second function of directive speech act, request, also used declarative and interrogative forms. The use of certain verbs tends to weaken the force of order, and to strengthen the implied messages.

(162) Be so kind as to walk home with him, will you? [Vol II, Ch.13,p 269] (165) Come, then, my hero. Are you willing to return, escorted by me? [Vol II, Ch.13,p 269]

Heathcliff in (162) and (165) strengthened his requests by using interrogative form in the end of his utterances to ask his addressees' willingness. Catherine Earnshaw, differently, used conditional clause as a polite expression if you please (30) to request her hearer's consideration, or an expression of desire $I$ wish (50) and for my sake (82) to show her expectation toward the hearer.

(30) 'Well, go, if you please [Ch.8,p 72]

(50) 'I wish you would speak rationally.' [Ch.9,p 79]

(82) 'I know you didn't like him, Yet, for my sake, you must be friends now.' [Ch.10,p 95]
Differently, Anne Bronte's Helen Graham softened her order by using I beg you or do as in (12) 'Mrs. Markham, I beg you will not say such things, in his presence, at least.' [Ch.3, p. 29] when she talked to Mrs. Markham about Arthur Graham (Helen Graham's only son), or she asked Gilbert to leave her alone by having $d o$ in (124) 'Gilbert, do leave me!' [Ch.12, p. 105] to replace please. Helen Graham's utterances also have interrogative form as in (95) 'Would you like to come in?'[Ch.10, p. 91], or (309) 'but be quick, will you, Rachel? I want to be dressed.' [Vol. II. Ch.22, p.200].

Gilbert Markham's utterances to Helen Graham initially contains an indirect request as in (19) 'I beg your pardon, Mrs. Graham' [Ch.3, p. 33], or (13) 'By no means, Mrs. Graham; pray let him stay. I am as much amused as he is,' [Ch.3, p. 30]. The use of I beg your pardon and pray softened his requests to a new inhabitant in their environment. Likewise, Edward Rochester in (16) 'I must beg of you to come here' [Ch.12 p.135] also softens his request to Jane Eyre, as he also wished Jane Eyre to greet him in (404) 'Come and bid me good-morning,' [Ch. 24, p. 298]. As suggested by Phoocharoensil (2010:233) referring to LDOCE (2009), the verb beg (comparing to the verb ask) suggests speaker's priority in the action which should be accomplished. It means that the characters weighed the requests before using the verb beg, they might consider their social status and relationship with the addressees.

Differently, Jane Eyre employed hedges in her request to Edward Rochester, (379) 'I have your permission to retire now, I suppose?' [Ch. 19, p. 235], it indicates that Jane Eyre's social position as the governess in Thornfield and Edward Rochester as the master of Thornfield influenced the use of I suppose in her request. In different request, Jane Eyre 
used a conditional clause if you please when requested a leave to Edward Rochester, she said (432) 'If you please, sir, I want leave of absence for a week or two.' [Ch. 21 p. 257]. The request was made as polite as possible, was different from Jane Eyre's request to Bessie (the helper in Gateshead), the utterance (28) 'Come, Bessie! don't scold.' [Ch 4, p.46] showed that Jane Eyre directly requested Bessie to stop scolding her. According to Hyland (2015:3-4), hedges in academic texts includes might/perhaps/possible/about indicating hesitance or secrecy of a whole statement.

In sum, the characters express request speech acts differently, depending on their relationship with the addressees. Gilbert Markham and Helen Graham used polite expression by adding $I$ beg at their first acquaintance, which also used by Edward Rochester to Jane Eyre at first. Jane Eyre used hedges and interrogative form to Edward Rochester showing her uncertainty in requesting to leave the room the her master.

In expressing suggestion, the study found that five characters use had better to emphasise their suggestions. The utterance (3) made by Heathcliff to Lockwood (the new tenant), while Catherine Earnshaw's suggestion in (9) expressed to Heathcliff, and Helen Graham's utterance in (146) was for Gilbert Markham. There was also Gilbert Markham's utterance (53) suggesting Lawrence, and Edward Rochester suggested Diana's action to Jane Eyre in (695). The suggestion of Jane Eyre in (833) addressed to St. John who insisted Jane Eyre to accept his marriage proposal.

(3) You'd better let the dog alone [Ch.1, p.6]

(9) 'you'd better go.' [Ch.8,p 69]

(146) 'so you had better leave the house at once, if you came only for that.' [Ch.15, p. 126]

(53) 'Then you had better let her alone.' [Ch.6, p. 56]
(695) 'She had better not wait till then, Jane,' [Ch. 38, p.518](833) Now you had better go; for if you stay longer, you will perhaps irritate me afresh by some mistrustful

scruple.' [Ch. 33, p.447]

Orders in directive speech act also found in all characters as in the utterances (214), (24), (1), (287), (55) and (281) respectively expressed by Heatchliff, Catherine Earnshaw, Helen Graham, Gilbert Markham, Edward Rochester and Jane Eyre.

(214) 'Drag her away!' [Vol II, Ch.19,p. 320]

(24) 'Leave the room, Ellen! [Ch.8,p 71]

(1) 'Give me the child!' [Ch.2, p. 25]

(287) 'Speak out, Miss Eliza! you needn't fear to say anything in my presence.' [Vol. III. Ch.47, p.420]

(55) 'Approach the table,' [Ch.13 p.146]

(281) 'Wake! wake!' [Ch. 15, p.174]

The orders in the aforementioned utterances have different objectives. Heathcliff ordered Hareton to punish Catherine Linton for being disobedient while dinner, while Catherine Earnshaw ordered Nelly as Edgar Linton came to Wuthering Height. In the utterance (1), Helen Graham ordered Gilbert Markham (her new neighbour) to refrain from her only son. Gilbert Markham, on the other hand, ordered Miss Eliza to continue her opinion about their new neighbour. In short, the orders made by Heathcliff, Catherine Earnshaw and Edward Rochester addressed to the addressees who have lower social status than they were, while Helen Graham and Gilbert Markham aimed to warn their addressees. In addition, the order was also aimed to warn the addressee about emergency, or incident that might be happened as in the utterance (281). The narration of Charlotte Bronte's Jane Eyre suggested that the emergency happened because there was fire in Edward 
Rochester's room. In brief, orders were expressed by the use of imperative form in order to get the addressee's attention and full commitment to future action.

In representative speech acts, Gilbert Markham's speech acts mostly consist of disagree, while another six character's speech acts tend to show the function of describing their intention. Catherine Earnshaw talked to Nelly described Heathcliff's intrigue leading Hindley to gamble in the utterance (91), while Heathcliff wanted Nelly to accompany her by describing the activities of each Wuthering Height's inhabitant.

(91) 'He explained it, I wonder as much as you. He said he called to gather information concerning me from you, supposing you resided there still; and Joseph told Hindley, who came out and fell to questioning him of what he had been doing, and how he had been living; and finally, desired him to walk in' [Ch.10,p 99-100]

(167) 'Hareton is gone with some cattle to the Lees, and Zillah and Joseph are off on a journey of pleasure; and, though I'm used to being alone, I'd rather have some interesting company, if I can get it. Miss Linton, take your seat by HIM.' [Vol II, Ch.13,p 270]

Helen Graham described her argument about false reasoning to her aunt in the following utterance, she described her opinion about the gentlemen in the room.

(173) 'I don't think it is false: I am an excellent physiognomist, and I always judge of people's characters by their looks-not by whether they are handsome or ugly, but by the general cast of the countenance. For instance, I should know by your countenance that you were not of a cheerful, sanguine disposition; and I should know by $\mathrm{Mr}$. Wilmot's, that he was a worthless old reprobate; and by Mr. Boarham's, that he was not an agreeable companion; and by Mr. Huntingdon's, that he was neither a fool nor a knave, though, possibly, neither a sage nor a saint-but that is no matter to me, as I am not likely to meet him again - unless as an occasional partner in the ball-room.' [Ch.16, p.136]

Gilbert Markham described Miss Wilson to Helen Graham in (91) "She is elegant and accomplished above the generality of her birth and station; and some say she is ladylike and agreeable.' [Ch.9, p. 86], as Helen Graham asked his opinion about the lady. Meanwhile, Edward Rochester described his experience when he was young in the following utterance:

(116) 'she charmed my English gold out of my British breeches' pocket. I have been green, too, Miss Eyre,ay, grass green: not a more vernal tint freshens you now than once freshened me. My Spring is gone, however, but it has left me that French floweret on my hands, which, in some moods, I would fain be rid of. Not valuing now the root whence it sprang; having found that it was of a sort which nothing but gold dust could manure, I have but half a liking to the blossom, especially when it looks so artificial as just now. I keep it and rear it rather on the Roman Catholic principle of expiating numerous sins, great or small, by one good work. I'll explain all this some day.' [Ch. 14, p.163164] 
(361) 'I don't know the gentlemen here. I have scarcely interchanged a syllable with one of them; and as to thinking well of them, I consider some respectable, and stately, and middle-aged, and others young, dashing, handsome, and lively: but certainly they are all at liberty to be the recipients of whose smiles they please, without my feeling disposed to consider the transaction of any moment to me.' [Ch. 19, p. 230]

The utterance (361) by Jane Eyre, on the other hand, was her description about her scant acquaintance with the guests of Edward Rochester in Thornfield Hall. In summary, the characters described issues which are still within their scope.

In agreeing to issues brought by the addressees, the characters usually responded by using affirmative answer (yes). It is actually in line with GruetSkrabalova (2016: 12) who found that positive answer (yes) may use to respond to interrogative form presented positively or negatively, as well as declarative form which expressed as negative questions. Besides, there are some expression found indicating the characters' consent toward the addressees' opinion, as seen in (273) Not at all, uncle; on the contrary, I should like to wait till after Christmas, at least.' [Vol. II. Ch.20, p.180], in which Helen Graham agreed to his uncle's suggestion on the date of her marriage with Arthur. Agreeing also expressed by the characters who allow the requests of their addressees, as seen in Edward Rochester's utterance in (484) 'You may.' [Ch. 25, p. 327]. From all characters, there were 32 affirmative responses of Jane Eyre, indicating that she preferred a simple response.

Commissive speech act is related to speaker's target in the future (Horn and Ward, 2006: 64). The commissive speech act found in all characters regarding to plan, refuse, promise and offer. The characters used modals in declarative form to highlight their future plans.
(2) 'I shall bid father good-night first,' [Ch.5, p.43]

(190) If Edgar Linton meets me, I shall not hesitate to knock him down, and give him enough to insure his quiescence while I stay. If his servants oppose me, I shall threaten them off with these pistols. [Ch.14,p 151-152]

(9) in future, I must contrive to bring him with me, or stay at home.' [Ch.3, p. 28]

(342) I want to get there tomorrow, and pass the night on the road' [Vol. III. Ch.52, p.470]

(443) 'I'll send her to school yet,' [Ch. 24, p. 307]

(580) 'I'll be preparing myself to go out as a missionary to preach liberty to them that are enslaved-your harem inmates amongst the rest. I'll get admitted there, and I'll stir up mutiny; and you, three-tailed bashaw as you are, sir, shall in a trice find yourself fettered amongst our hands: nor will I, for one, consent to cut your bonds till you have signed a charter, the most liberal that despot ever yet conferred.' [Ch. 24, p. 310]

The use of modals seen in (2) and (190) as it explains in the narration of Wuthering Heights that Catherine Earnshaw's father was in bad condition, her family suggested her to leave her father; thus, before leaving her father, she greeted him first. Heathcliff, on the other hand, used modal to show his alternative responses toward Edgar Linton. The use of adverb of time also indicates the plan of the characters as seen in one of Helen Graham's utterance in (9) which used in future, as well as adverb tomorrow in the utterance (342). In addition, the use of modal in (342) and (443) is regarding to 
Edward Rochester's and Jane Eyre's future plan.

The characters expressed refusal by using declarative form, rather than using direct refusal, the utterance (184) 'I would rather not speak of her now.' [Ch.13, p. 112] which was Gilbert Markham's refusal to Eliza Milward. The findings indicated that refusal reflected the characters' unwillingness toward the addressees' offers; thus, the expression of refusal also includes the characters' reasons which justify their refusal.

Promises include in one of commissive speech acts, expressing the speaker's commitment to do something for others. The researchers found that promises were committed by the characters who were willing to accept the addressees' requests and offers, as seen in Helen Graham's utterance (523) 'I shall not tell him.' [Vol. II. Ch.34, p.311], or Heathcliff's promise to Catherine Linton in (174) Once in your own room, I'll not come near you: you needn't fear. By chance, you've managed tolerably. I'll look to the rest. [Vol II, Ch.13,p 273].Furthermore, Gilbert Markham promised Helen Graham that (99) '.. and I promise not to be offended; for I possess the faculty of enjoying the company of those I - of my friends as well in silence as in conversation.' [Ch.9, p. 85]. In short, promises were not only highlighted by the use of verb promise, but also highlighted by the use of modals.

The last commissive speech act used by all male and female characters in Bronte sisters' novels is offers. The researchers found that the offer means that the offerer/speaker provides two options to the addressees.

(54) Therefore, Mr. Fergus, if you choose to enter my house as a friend, I will make you welcome; if not, I must confess, I would rather you kept away.' [Ch.7, p. 62]

(542) 'Jane! will you hear reason?' (he stooped and approached his lips to my ear); 'because, if you won't, I'll try violence. [Ch. 27, p. 349]

(486) 'Love me, then, or hate me, as you will,' I said at last, 'you have my full and free forgiveness: ask now for God's, and be at peace.' [Ch. 21 p. 275]

The utterance (54), (542) and (486) were made by Helen Graham, Edward Rochester and Jane Eyre, respectively. They offers two alternative solutions to their addressees, containing positive and negative solutions, i.e. the utterances (54) and (542) have if not, if you won't, while the utterance (486) has an offer as you will allowing the addressee's willingness or preference.

The male and female characters of Bronte sisters' novels expressed their hope, disappointed, regret or anger to addressees using declarative form, highlighting the verbs indicating the expressive speech acts, such as (111) 'I expect you to feel flattered' [Ch.10,p 105] shows Catherine Earnshaw's expectation, or (322) 'If you had told me these things before, Arthur, I never should have given you the chance.' [Vol. II. Ch.24, p.209] was Helen Graham's regret toward Arthur Huntingdon's conduct which seen in the use of conditional clause. In addition to expressing their emotion, all six characters also expressed their worry, insult, praise, condolence and greeting.

In expressing worry, the researchers found that the exclamation as in Heathcliff's utterance (102) 'Oh, Cathy! Oh, my life! how can I bear it?' [Vol II, Ch.1,p 159], and the expression of anxiety found in (149) 'I am afraid, Nelly, I shall lose my labour,' [Vol II, Ch.7,p 217], as well as Jane Eyre's utterance (894) 
" 'Deeply: he will never forgive me, I fear: yet I offered to accompany him as his sister.' [Ch. 35, p.478]. The expressive speech act was not only delivered in declarative form, but also interrogative form as in (434) 'Then, you will leave me again, Arthur?' [Vol. II. Ch.30, p.263], or (384) 'Do you feel ill, sir?' [Ch. 19, p. 235]. In short, the expression of worry can be seen by the use of adjective afraid, verb fear, exclamation indicating shock, or interrogative form following the conclusion. Differently, the expression of insult can be seen from the use of epithets in you naughty fondling (98), you neophyte (99), the devil (181) referring to the hearers:

(98) 'How can you say I am harsh, you naughty fondling?' [Ch.10,p 102]

(99) 'You have no right to preach to me, you neophyte, that have not passed the porch of life, and are absolutely unacquainted with its mysteries.' [Ch. 14, p.160]

(181) 'I'd rather be hugged by a snake. How the devil can you dream of fawning on me? I DETEST you! [Vol II, Ch.13,p 275]

Thomas (2010: 14) actually described the hearer's trait or the relationship between the speaker and hearer. The aforesaid utterances were epithets which made of the characters' judgement on the addressees' traits. Besides, insults consisted of the speaker's personal expression after being offended by the addressees' utterances or actions.

(43) 'I am glad you are no relation of mine: I will never call you aunt again as long as I live. I will never come to see you when I am grown up; and if any one asks me how I liked you, and how you treated me, I will say the very thought of you makes me sick, and that you treated me with miserable cruelty.' [Ch 4, p.44]

(518) 'I am no bird; and no net ensnares me; I am a free human being with an independent will, which I now exert to leave you.' [Ch. 23, p. 293]

The utterance (43) addressed to Mrs. Reed since she always wrongfully treated Jane Eyre and planned to send her away to Lowood, the boarding school. In the meantime, the utterance (518) was delivered to Edward Rochester who compared Jane Eyre to the bird, and she was offended by his description. Praise and condole, on the other hand, aimed to please the addressee; thus, the researchers found adjectives describing the goodness of the hearers. In summary, expressive speech acts might be seen by the use of exclamation, adjectives, verbs or epithet in declarative or interrogative forms.

The researchers already described that six characters (Catherine Earnshaw, Heathcliff, Gilbert Markham, Helen Graham, Edward Rochester and Jane Eyre) have directive, representative, commissive and expressive speech acts. Only five of six characters that have declarative speech acts, the utterances (3), (134), (577), (95) and (944) respectively uttered by Catherine Earnshaw, Heathcliff, Helen Graham, Edward Rochester and Jane Eyre:

(3) 'Oh, he's dead, Heathcliff! he's dead!' [Ch.5, p.43]

(134) 'You are my son, then, I'll tell you; and your mother was a wicked slut to leave you in ignorance of the sort of father you possessed.' [Vol II, Ch.6,p 208]

(577) ' I confess I was wrong, but whether want of courage or mistaken kindness was the cause of my error, I think you blame me too severely. I told Lady Lowborough two weeks ago, the very hour she came, that I should certainly think it my duty to inform you if she continued to deceive you: she gave me full liberty to do so if I should see anything reprehensible or suspicious in her conduct; I have seen nothing; and I trusted she had altered her course.' [Vol. III. Ch.38, p.342] 
(95) 'I am not a villain: you are not to suppose that — not to attribute to me any such bad eminence; but, owing, I verily believe, rather to circumstances than to my natural bent, I am a trite commonplace sinner, hackneyed in all the poor petty dissipations with which the rich and worthless try to put on life.' [Ch. 14, p.158]

(944) 'I told you I am independent, sir, as well as rich: I am my own mistress.' [Ch. 37, p.501]

The preceding utterances were declarative speech act since they declared new condition, changed social status, confession or attribution.

\section{Conclusion}

The utterances of six characters of Bronte sisters' novels (Catherine Earnshaw, Heathcliff, Edward Rochester, Jane Eyre, Helen Graham and Gilbert Markham) consist of directive, representative, commissive and expressive speech acts, and only Gilbert Markham's utterances which did not have declarative speech act. Directive speech acts (ask, request, suggest and order) were presented in interrogative, declarative and imperative forms. The analysis suggested that the use $\mathrm{WH}$ question, modals and auxiliary verbs in interrogative form, and declarative form used question tags. Meanwhile, directive speech acts functioned as orders, especially, expressed in imperative to get the addressee's attention and full commitment to future action. Differently, representative speech acts (describe, report, claim, conclude and agree), commissive speech acts (plan, refuse, promise, offer) and declarative (declare) were mostly presented in declarative form. Expressive speech acts (offend/insult, worry, general expressive, praise, condole dan greet) found in all characters, on the other hand, not only employed declarative form, but also interrogative form.
Beside the structure, speech acts in these novels highlight the use of address term, epithet, expression (verb, adjective, modal verbs), exclamation, conditional clauses, hedges and affirmative answer. Briefly, address term and epithet explained the relationship between the characters and their addressees, as well as described the traits of the addressee based on the characters' judgement. The address terms used in directive speech acts have similar reasons with Rifai and Prasetyaningrum (2016:133), especially mockery, intimacy, mockery, power and respectful. Expression (verb, adjective, modal verbs) and exclamation indicate types of speech acts, supported by the situational context. The findings were not in line with Zakalashvili and Avagyan (2016:82) who argued that the use of modal verbs determined the weight of obligation (weak or strong), in which women tend to use the weak one, because the recent study found that both female and male characters of Bronte sisters' novels used modal verbs to deliver their messages to the addresses. Likewise, hedges, according to comprehensive data analysis, were mostly found in Helen Graham, used by male and female characters because of some reasons: initial acquaintance influencing intimate relationship, and social status. Conditional clause, on the other hand, found not only in directive speech acts (request and suggest), but also commissive speech act (offer) and expressive speech act (regret), while the discussion of affirmative answers which is in line with Gruet-Skrabalova (2016: 12) found mostly in Jane Eyre.

After dealing with the classification of speech acts on a great number of utterances in three novels, the researchers recognise the shortcomings of this analysis; thus, the next researchers should be able to focus on discussing the interface between speech acts and the linguistic 
components which are partially discussed in this study.

\section{References}

Ariyanti, Lisetyo. (2007). Understanding The Characterization of Main Character in Wuthering Heights from His Several Kinds of Speech Acts. Proceeding PESAT (Psikologi, Ekonomi, Sastra, Arsitek \& Sipil) Vol. 2 Auditorium Kampus Gunadarma, 21-22 Agustus 2007 ISSN : 1858 - 2559.

Busse, Ulrich. (2008) An inventory of directives in Shakespeare's King Lear. Jucker, Andreas $\mathrm{H}$. Taavitsainen, Irma (eds). Speech Acts in the History of English (Pragmatics \& Beyond New Series, issn 0922-842X ; v. 176). Amsterdam: John Benjamins Publishing Company

Bronte, Anne. (1996). The Tenant of Wildfell Hall. Davies, Stevie (ed). England: Penguin Books

Bronte, Charlotte. (2006). Jane Eyre. Davies, Stevie (ed). England: Penguin Books

Bronte, Emily. (1995). Wuthering Heights. Davies, Stevie (ed). England: Penguin Books

Doub, Andrew. (2015). I Could Do with Less Caressing: Sexual Abuse in the Tenant of Wildfell Hall. Criterion: A Journal of Literary Criticism, Volume 8 Issue 2, Article 5.

Gruet-Skrabalova, Hana. (2016) Yes or No, or How to Answer a Negative Question. Linguistica, Ljubljana University Press, Faculty of Arts 2016, Current Trends in Generative Linguistics, 56, pp.127-142. $<10.4312 /$ linguistica.56.1.127142>. <hal-01679867>

Hyland, Ken. (2015). Metadiscourse. The International Encyclopedia of Language and Social Interaction, First Edition. https://www.researchgate.net/profil e/Ken_Hyland/publication/2855915 98_Metadiscourse/links/59ddf79d0 f7e9bec3bae06ad/Metadiscourse.pd $\underline{f}$

Horn, Laurence R. Ward, Gregory. (2006). The Handbook of Pragmatics. Cornwall: Blackwell Publishing Ltd.

Hsieh, Hsiu-Fang. Shannon, Sarah E. (2005). Three Approaches to Qualitative Content Analysis. Qualitative Health Research, Vol. 15 No. 9, November 2005 12771288. DOI: $10.1177 / 1049732305276687$

Kuckartz, U. (2013). Qualitative Text Analysis - A Guide to Methods, Practice and Using Software. Los Angeles: Sage

Leech, Geoffrey. Short, Mick. (2007). Style in Fiction, A Linguistic Introduction to English Fictional Prose. Great Britain: Pearson Education Limited

Phoocharoensil, Supakorn. (2010). A Corpus-Based Study of English Synonyms. International Journal of Arts and Sciences, 3(10): 227 - 245 (2010)

Rifai, Dian Muhammad. Prasetyaningrum, Sevian Tri. (2016). A Sociolinguistic Analysis of Addressing Terms used in Tangled Movie Manuscript. Jurnal Penelitian Humaniora, Vol. 17, No. 2, Agustus 2016: 123-134

Rohmah, Zuliati. (2011). A Speech Act Analysis of Jane Eyre. Academic Journal: Language in India;Feb 2011, Vol. 11 Issue 2, p376

Sadock, Jerrold. 2006. Speech Acts in Lawrence R.Horn and Gregory Ward (Eds) The Handbook of Pragmatics. Australia: Blackwell Publishing Ltd.

Taavitsainen, Irma. Andreas H. Jucker. 2008. Speech Acts Now and Then: Towards a Pragmatic History of English. Jucker, Andreas $\mathrm{H}$. 
Taavitsainen, Irma (eds). Speech Acts in the History of English (Pragmatics \& Beyond New Series, issn 0922-842X ; v. 176). Amsterdam: John Benjamins Publishing Company

Thomas, Margaret. 2010. Names, Epithets, and Pseudonyms in Linguistic Case Studies: A Historical Overview. Names A Journal of Onomastics 58(1): 13-23. doi:10.1179/175622710X12590782 367982.

Wang, Ya-huei. Women, Marriage and Economy in Jane Eyre. Journal of Literature, Language and Linguistics Volume 3, Issue 1, 2011.

Yang, CM. 2012. A Deleuzian Reading of Wuthering Heights: The Micropolitics of Minorization. Arts and Social Sciences Journal, Vol. 2012: ASSJ-4.

Yiyin, Zhu. A Study of Conversations in Wuthering Heights From The Perspective of Cooperative Principle. Thesis, Dissertations,
Professional Papers. Shanghai International Studies University. 2014.

Zakalashvili, Lusine. Avagyan, Naira. Modal Verbs of Obligation in Quotations and Political Discourse. Armenian Folia Anglistika 2(16)/2016.

http://publications.ysu.am/wpcontent/uploads/2017/07/8LusineZakalashvili.pdf

\section{Acknowledgement}

This article was one of research outcomes of PDP (Penelitian Dosen Pemula) in 2018. The researchers would like to thank DRPM Kementerian Riset, Teknologi dan Pendidikan Tinggi Republik Indonesia for funding PDP project under SK No. 0045/E3/LL/2018 (duration: 22 February to 16 November 2018). 